\title{
The evolution of rural areas influenced by large-scale farming: four case studies from Hungary
}

\author{
György Mikle (1) Filippo Randelli
}

Published online: 17 June 2020

(C) The Author(s) 2020

\begin{abstract}
In order to study complex transformation of rural areas in the long term, our paper aims to integrate the concepts of rural restructuring and evolutionary economic geography. We argue that these approaches can complement each other to understand the mechanisms shaping rural evolutionary paths. We apply our theoretical framework to the case of rural areas evolving under the influence of largescale farms in Hungary, namely the so-called manorial settlements. Tracing the processes on three different scales (global, national and local) we claim that during the last one hundred years the rural configuration in these areas shows a number of continuities despite the significant political-economic transitions throughout this period. The global dependency and semi-peripheral position of Hungary is apparent, and also the role of global agri-food regimes can be observed. Political transitions on the national scale appear primarily as 'external shocks'. Despite the strong path dependency in terms of powerlessness and passivity of local societies at manorial settlements, the role of certain local actors in path creation should not be ignored.
\end{abstract}

G. Mikle $(\square)$

Doctoral School of Earth Sciences; Department of Social and Economic Geography, Eötvös Loránd University, Budapest, Hungary

e-mail: miklegy@student.elte.hu; miklegyo@gmail.com

F. Randelli

Department of Economics, University of Florence,

Florence, Italy

\section{Introduction}

Rural geography and the analysis of agriculture underwent a number of 'turns' during the last decades: different approaches emerged which resulted in changes regarding research questions, theories and methods (Cloke 1997; Maclaren 2019; Morris \& Evans 2004; Woods 2005). At the same time, the analysis of rural economies has interested economic geography as well, with a renewal in the approaches by scholars (Woods 2009). The goal of this paper is to combine the rural restructuring approach (grounded in political economy) and the concepts of evolutionary economic geography (EEG) for the study of the changes occurring to rural areas.

The term rural restructuring in the western context was used by authors investigating complex transformations and deep macrostructural changes, which manifest in qualitative transformations of the economic production, the role of the state and the civil society (Cloke \& Thrift 1987; Hoggart \& Paniagua 2001a, b; Thrift 1987). This body of literature predominantly takes the political economy approach, since it focuses on the interplay between the political and economic realms (Cloke 1989; Woods 2005). In this paper we argue that besides paying attention to the role of political-economic power in affecting economic transformations, a dynamical approach is needed in order to explain the role of routines and organisational models inherited from the past in 
shaping the way of transformations (Martin \& Sunley 2006).

In order to better understand the transformation of rural areas, we develop a theoretical framework by integrating the rural restructuring approach and the key concepts of EEG. By doing so we wish to discuss the relevance and applicability of these approaches in a post-socialist context. In the post-socialist countries, the social and economic transitions in the countryside during the second half of the twentieth century are often considered as restructuring processes (e. g. Csurgó et al. 2018; Kovách 2012; Kovács 2005), which were primarily led by political decisions. However, to reveal the material appearance of these transformations, it is promising to pay attention to the processes on the local scale, by focusing on the changing strategies and practices of local actors. As we aim to show below, rural restructuring refers to a complex set of changes (in the role of the state, economic production and local society) driven by political and economic power relations, while EEG is a more relational view focusing on how the economic landscape is shaped through mechanisms of path creation and path dependence driven by different actors (be they individuals or firms).

To put these theoretical considerations into practice, we analyse the evolutionary path of rural areas in Hungary, where the economic production was carried out in large-scale farms from the mid-nineteenth century. The features of agricultural production on the national scale is well-documented for the period before World War II (e. g. Berend \& Ránki 1976; Gunst 1970), for the state socialist period (e. g. Hann 2003; Juhász 2006; Klenczner 1996; Schlett 2015; Varga 2010, 2014), and also in terms of the processes and outcomes of the transition starting in the 1990s (Kovács 2016; Kovách 2016). It is apparent throughout this body of literature that despite changes in technology, methods of production and labour organisation, large-scale farms' presence is a rather continuous phenomenon in Hungary in the long term. These farms are usually exceeding a thousand of hectares in size and are oriented in production towards (international) markets.

The four case studies are on the so called manorial settlements, which were the backbones of large-scale farming until World War II. Scholarly investigation of manorial settlements have already revealed the production practices, working and living conditions under large estates (capitalist latifundia) (Erdei 1974; Féja 1938; Illyés 1993; Tamáska 2013), the transformation of this system during state socialism (e. g. Csoóri 1963; Lampland 2016), and the role of the postsocialist transition (Kovács \& Vidra 2012; Németh 2016, 2019). These places are usually seen as localities almost entirely shaped by the logic of large-scale agricultural production, and were characterised by a minor role of public administration bodies and local society in shaping the local developmental paths. For this reason, the investigation of these localities can provide insight into the practical functioning of largescale farms in different eras. In our view, integrating the rural restructuring approach and EEG might help to put the transformation of the system analysed in an international context: on the one hand we hope to contribute to the scholarly debate on the applicability of 'western' concepts in post-socialist settings, while on the other we aim to provide additional conceptual viewpoints on the research of agricultural restructurings in East Central Europe.

This paper is structured as it follows: in chapter two we introduce the theoretical framework and empirical methods; chapter three we turn to the empirical analysis and we point out four different evolutionary steps; the analysis will be applied to three different geographical scales (global, national and local); in chapter four we report some findings and conclusions. The paper is built upon the re-reading of scholarly literature documenting the abovementioned transitions, census data, documents of local history and interviews. Empirical case studies were carried out in four manorial settlements, where current and former inhabitants and experts (former and current municipal leaders, agricultural intelligentsia working for largescale farms) were interviewed. All the manors presented in the case studies are located in the northern part of Transdanubia.

\section{Theory and methods}

The transformations of the rural economy in Hungary in the last century or so are often seen as restructuring processes influenced by political transitions. At the same time in western contexts the bottom-up approach of EEG is emerging, which focuses on the role of individuals and firms in driving economic changes (Boschma \& Frenken 2006). We argue that EEG and 
the rural restructuring approach can complement each other and help us to interpret the mechanisms that drove the changes. Theoretical investigation of the integration of EEG and political economy is not unprecedented as it has been used as conceptual framework for empirical analysis (e. g. Mackinnon et al. 2019). Our paper aims to provide additional insights to this topic by taking a long-term approach and by structuring the argument on three distinctive geographical scales: global, national and local.

On the global scale, we look at the large-scale farms' embeddedness in the world economy; in a broader sense, we trace Hungary's changing global integration. According to the appliers of world system theory (Böröcz 1992), Hungary has a semi-peripheral position, which results in dependency upon global political and economic power relations, and which has a major and in many cases direct impact on local processes (Geröcs \& Pinkasz 2017; Pósfai 2018). The theory of global agri-food regimes (Friedmann \& McMichael 1989; McMichael 2009) poses similar questions, as it scrutinizes the global dependency systems as major drivers of change within the argifood economy. We evaluate the Hungarian large-scale farms' changing production methods and organisational forms in the light of these shifting systems of dependency.

For the investigation of national scale processes, we stress the importance of the restructuring approach, and apply the lens of political economy (Cloke 1989; Hoggart \& Paniagua 2001a, b; Woods 2005). This approach is relevant, because during the twentieth century significant political transitions happened in Hungary, which resulted in large differences regarding political philosophy and class politics; individual action has often been constrained. Here the focus is on the major features of the economic environment on the national scale and the role of state policies in affecting its formation. Another key point is the alteration of large-scale agricultural production as an outcome of the differing political systems.

Any shift within a rural economy is not a linear process, as it involves experimentation, learning processes, new capabilities, new policies, adjustment and reconfigurations. In addition, the geographical dimension of the transition changes the background of every process. In order to reveal the dynamics and mechanisms that affect a rural transition, this paper suggests to draw the analysis upon recent EEG literature (Boschma \& Martin 2010). As Boschma and Martin (2007) put it, EEG is concerned with how the processes of path creation and path dependence interact to shape geographies of economic development and transformation.

The economic landscape does not tend towards some (predefined) unique equilibrium state or configuration, but is an open system that evolves in ways shaped by its past development paths (Martin \& Sunley 2006). In order to reveal the rural transition processes this paper stresses the analysis of past development paths within rural regions. Our aim is to investigate the local path dependency and path creation in a micro-level view, by tracing the actions of the most important local actors (farm leadership, local state, local inhabitants) within each periods. Path dependency is seen to be formed largely by local economic histories through the routines inherited from the past. Path creation can happen in different ways (Martin \& Sunley 2006), but the role of the broader institutional and economic context is important in helping or blocking certain ways of innovation (Boschma \& Frenken 2006; Essletzbichler \& Rigby 2007; Randelli et al. 2014; Randelli \& Martellozzo 2019).

Broadly speaking, we will explain economic transitions as a shift from a historically predominant configuration to a new one, by the interplay of processes at three different levels: micro (local), meso (national) and macro (global). The key concept is the rural configuration within a region, which concerns with production process techniques, farm organisation, land use pattern, infrastructures and rural settlements. A rural configuration deals with the semicoherent set of rules that orient and coordinate the activities of the rural actors. On the one hand, actors enact, instantiate and draw upon rules in concrete actions in local practices; on the other hand, rules configure actors (Giddens 1984). Examples of rules are cognitive routines and shared beliefs, capabilities and competences, lifestyles and user practices, favorable institutional arrangements and regulations, and legally binding contracts (Geels 2012).

A total of 32 semi-structured interviews constitute the backbone of our case studies, which were carried out between 2018 autumn and 2020 spring at manorial settlements and the neighbouring communities. Three major groups of interviewees have been current inhabitants, former inhabitants and experts. From the 
side of current inhabitants (22 interviews), we aimed to get insight into how local society adopted to globaland national-scale restructuring processes and to what extent were they able to take part in path creation. When it was necessary, we got in touch with former inhabitants ( 2 interviews). These people were working for the large-scale farms analysed during the state socialist era, but left the manors during the 1970s. They provided us further aspects of local economic history, and made us better understand the reason why a number of people left the localities.

Among the experts (8 interviews), we interviewed current members of local governments to see the role of these public administration bodies in affecting local processes and how they evaluate the past, present and future possibilities of local economy and societies. In order to analyse the possibilities of large-scale farm leadership in path creation during state socialism, and to get a view on the political transition and privatization beginning in the 1990s from a bottom-up perspective, we asked some of the former municipality leaders and former members of the agricultural intelligentsia who started their career during the state socialist period, to share their experiences on the mechanisms shaping local processes during the last couple of decades. Besides personal roles and experiences regarding economic history, we also focused on the relationship between these different groups of actors. Interviews were in Hungarian; they were recorded and transcribed. We use numbers (manors number I., II., III. and IV.) instead of the localities' real names for reasons of anonymity. We evaluate these interviews in the light of global- and national-scale processes documented by existing scholarly literature. This analysis would help us understand the local manifestation of the abovementioned processes and the role of the local-scale actors in shaping development paths.

\section{Rural evolution influenced by large-scale farming}

Building modernised large-scale farms (1848-1945)

Hungary's position, similarly to other economies in East Central Europe, is considered to be semi-peripheral in the international division of labour since the establishment of the capitalist world economy
(Brenner 1976; Wallerstein 1974) a dependent position further reinforced by the internal taxation system of the Habsburg Empire, which Hungary was a part of that time. Due to this system, Hungary became the provider of raw agricultural products. When the legislative introduction of capitalist economic principles occurred in 1848, most of large estates have already relied upon hired labour. However, these processes were further triggered by state policies, and large estates intensified their agricultural production. The estates produced grain crop in large amount to the international agricultural markets, and many of them was specialised in beef production (Gunst 1970; Vigvári \& Gerőcs 2017). In this period, the 'first food regime' dominated the Great Britain-centred world economy, which demanded the abovementioned raw products, primarily from the colonies and settler states (McMichael 2009).

On the national scale, the legal environment and power relations resulted in significant land concentration, and protected status quo of large estates. Besides the large-scale production, small-scale agriculture was also present in many parts of the country; these two models represented two different organisational modes (Juhász 2006; Kovách 2016; Maurel 2012). Large estates were market-oriented, many of them reached high levels of modernisation, and some of their products were processed by themselves (in distilleries, or sugar factories). The workforce consisted of agricultural servants with one-year contract, and agricultural labourers or poor peasants (some of whom came from the neighbouring villages, but masses of them were recruited at distant parts of the country) during the harvest season.

Modernisation manifested first of all in the factorylike mode of organisation and rational production philosophy (Féja 1938; Illyés 1993; Lampland 2016; Tamáska 2013). This model evolved first in private estates, but in the last decades of the nineteenth century it was also adopted by state-owned estates. On the other hand, most smallholdings were family-based peasant farms, trying to sell their products at the local or nearby markets, and in many cases these families were almost self-sufficient. Even if in many parts of the country these two models existed next to each other, in some areas only one of them was predominant. The southern part of the Great Plain, the eastern and southern territories of Transdanubia were almost 
entirely owned by large estates (Beluszky 1999; Tamáska 2013).

On the local scale, manorial settlements became the centre of production at large estates. Figure 1 shows an example of the settlement network that evolved under the influence of large estates. As it can be seen, manors were built at the peripheral, non-housing zones of municipalities. They belonged to the neighbouring village or town de jure, but in most cases they were detached from the municipality centre physically and usually the role of public administration bodies was minor in influencing local evolutionary processes and path creation. At these localities, the owners and the stewards (farm managers) were the most important actors (Gyáni et al. 2004; Féja 1938; Illyés 1993; Mikle 2018; Németh 2019). Stewards organised the everyday work in manorial settlements, they were responsible for making the production as efficient as possible, and they had to be aware of all the production stages. Manors consisted of buildings to serve the production (granaries, stalls), administrative and representative buildings, and houses for agricultural servants. Local inhabitants were predominantly servants, who had little or no impact on the path creation processes. However, it is also documented that occasionally servants were provided by the estates with small plots where they were able to carry out small-scale production in order to cover their basic household consumption needs (Illyés 1993; Féja 1938). In the beginning of the twentieth century the average population of these settlements ranged from 40 to 200 differing in each county (Balogh \& Bajmócy 2011; Erdei 1974). Most large estates consisted of more than one manor, eventually located at the territory of numerous municipalities.

The manors analysed in our case studies are located at the northern part of Transdanubia (Fig. 2). This area was continuously among the better-off regions of Hungary during the last century (Györi \& Mikle 2017), and also it was involved in the industrialisation relatively early. Although this region was not entirely dominated by large estates before World War II, their presence and impact on the rural configuration (especially production practices, land use and settlement network) was important. Two well-known stateowned estates were located here, wealthy churches

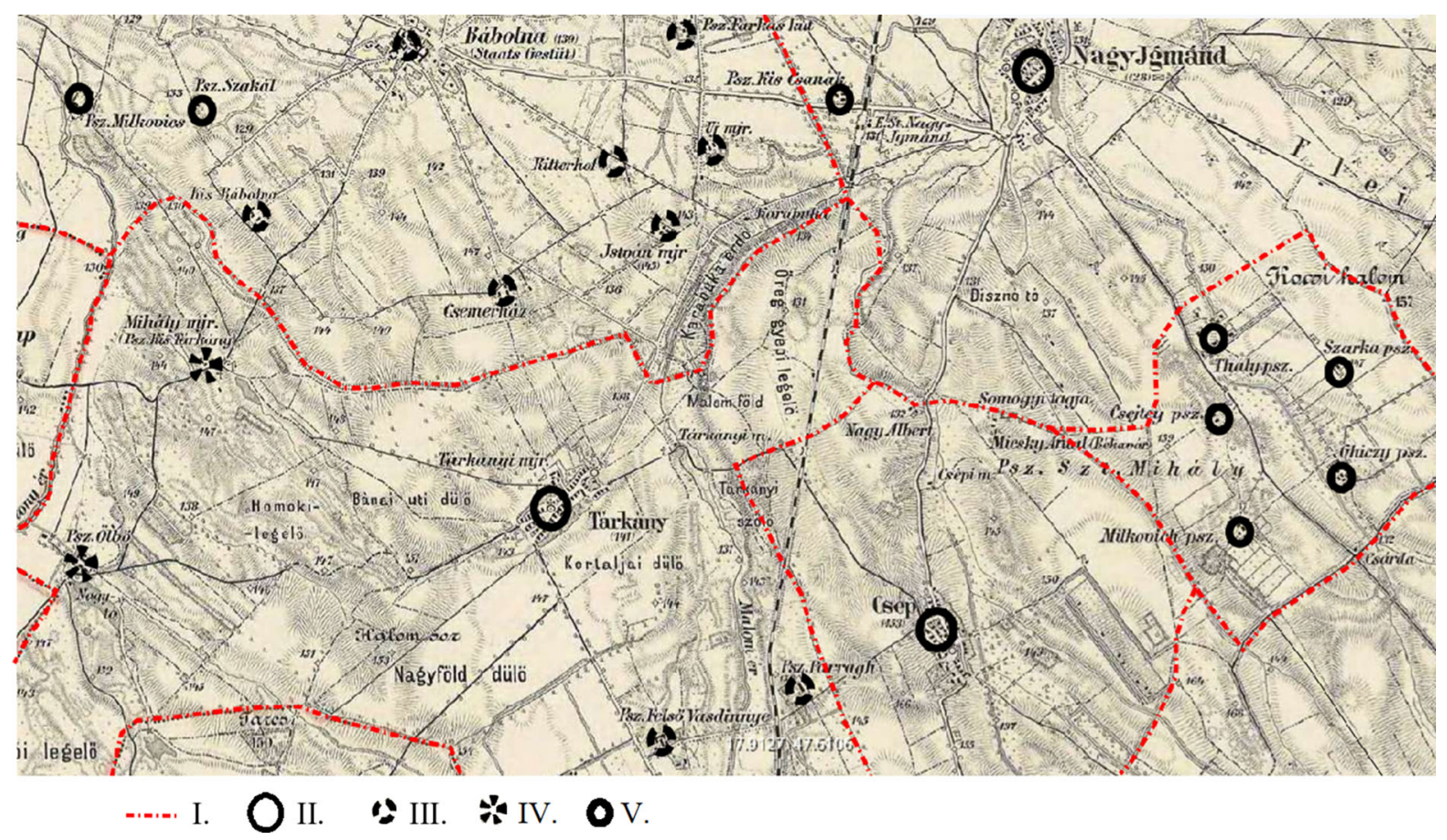

Fig. 1 Settlement network and public administration system in northern Transdanubia (late nineteenth century). I.-Community border, II.-Community centre, III.-State-owned manors, IV.-Church-owned manors, V.-Manors owned by noble families. Source: Edited by the author, based on 'Habsburg Empire (1869-1887)—Third Military Survey (1:75,000)'; mapire.eu 


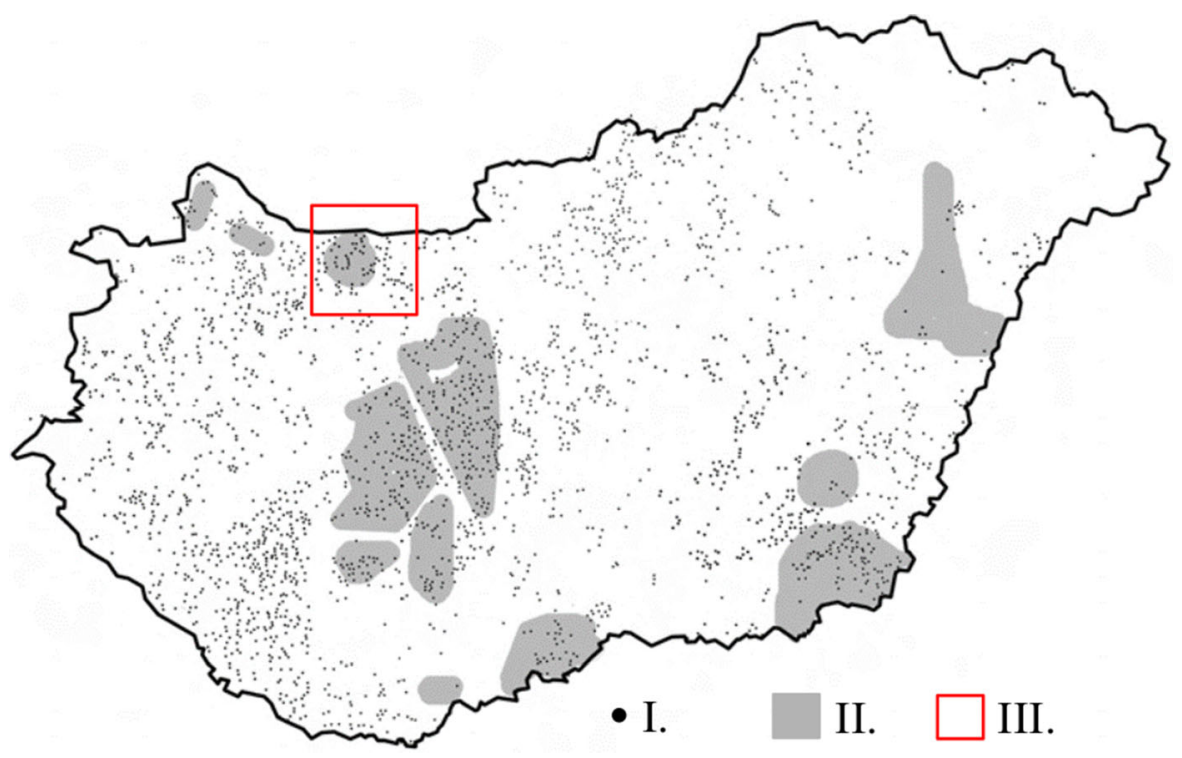

Fig. 2 Manorial settlements in Hungary in the nineteenth century and the area of the case studies. I.-CManor, II.-Chernozem area, III.-Area of the case studies. Source: Edited by the author, based on Tamáska (2013), p. 18

and noble families held significant amount of land in this area.

Based on agricultural census and documents on local history, it can be seen that all of the localities analysed had different owners and were characterised by slightly different economic activities at the beginning of the twentieth century. Manor no. I. belonged to one of the four state-owned large estates of that time. These estates were established as royal stud-farms: they were responsible for breeding and training horses for military purposes. Later they became responsible for generating profit and to be the exemplar of large estates by applying up-to-date production technologies (Molnár and Szabóné Medgyesi 1987). In manor no. II. more families had buildings at the same time, the neighbouring lands were owned by these families. Besides crop production, the main profile of these estates was beef and pork production. Manor no. III. belonged to one of the most known noble families of Hungary. The estate occupied the territory of more municipalities and was specialised in breeding sheep. Manor no. IV. was owned by a noble family of local significance.
Re-organisations and the Stalinist period (1945-1960)

After World War II Hungary found itself in the Soviet geopolitical sphere of influence, which constrained the way of integration in the world economy. The goal of the Soviet leadership was to separate the countries under its influence from the other parts of the world economy and to export the 'Soviet model' of organizing the society (Böröcz 1992; Geröcs \& Pinkasz 2017). During the first fifteen years, international trade and economic exchange took place in large part among the Comecon countries, the agricultural export headed primarily towards the Soviet Union.

Right after World War II a land reform took place in Hungary which aimed to redistribute large estates, and give land to the landless (including former agricultural servants and agricultural labourers). Between 1945 and 1948 a democratically elected government was in charge which supported individual peasantry and small-scale agricultural production. However, in 1948, due to the increasing Soviet influence, the Hungarian Working People's Party started to rule the country, started to nationalise private property and set up Soviet-type planned economy. In this era, the state was the primary driver of economic transformations in two important respects. First, the aim was to eliminate competition and capitalist market relations, and 
second, the state became the most important economic actor, as the nationalisation of previously existing companies and foundation of new state-owned companies took place.

This era was characterised by an anti-rural and antipeasant attitude, and the propagation of heavy industry. In agriculture, state farms and co-operative farms were established; in practice, the reorganisation of large-scale farming began (Maurel 2012), although the state propaganda opposed to the pre-World War II era. Despite this clear opposition, some aspects of continuity can be highlighted: in many cases, the former land of the large estates gave the basis of newly set-up state farms, and many of the former personnel stayed at the same position. ${ }^{1}$ It was true not only in the case of former servants (Sik \& Tausz 1978), but also many of the former manorial stewards became part of the new agricultural intelligentsia (Lampland 2016). The structure of work organisation and division of labour was also similar (Csoóri 1963; Izinger 1981; Juhász 2006; Mendöl 1963). Since state farms became responsible for transmitting the know-how of up-todate production technologies, in the case of former stud-farms it is another point of continuity.

Similarly to the previous era, the local state still had little role in shaping local economic evolution at manorial settlements as the expert interviews have shown. Socialist agricultural companies were responsible for the labour organisation, working conditions and local living conditions, although farm leadership was bound to central state directives, which largely affected the development of the rural configuration. However, under the two different models of socialist farms (state farms and co-operatives), the organisational structure and the status of the workforce was different as it can also be seen from our case studies. The insight to this era from interviews with current inhabitants is limited, as we found very few people who have already worked at these localities before the 1960s. However, documents of local history and scholarly literature complemented our knowledge regarding local path creation processes.

\footnotetext{
${ }^{1}$ On the contrary, for the former individual smallholders and peasants this new system meant radical changes in their way of life, and production since they had to give up individual cultivation and private land property, which was reached through their aggressive insult by the state authorities. By the first half of the 1960s the collectivisation was finished which led to the depeasantization of Hungary.
}

In the case of manor no. I., the lands remained stateowned, as a state farm was organised on the basis of the previous stud-farm. Besides continuing horsebreeding, the farm bred cows in large amount. Manor no. II. was organised into a state farm as well, and started a similar evolutionary path like manor no. I. In both manors, interviews with experts and elderly inhabitants show that the former practice of short-term employment of migrant labour during the harvest season remained part of the work organisation; it is one of the old routines that remained untouched despite the political transition. Another point of continuity is that the local population had minor role in affecting local processes, and production practices as they were state employees.

At manors no. III. and IV. new agricultural cooperatives were organised. In contrast to state farms, co-operative members were expected to organise the production themselves. Contemporary propagandistic reports on setting up co-operatives at manorial settlements emphasized the significance of the historical possibility for former servants to govern their own fate. However, another narrative was that in most cases former servants were unable to govern cooperatives, as they were socialised as physical workers with one single task (Sik \& Tausz 1978). This way of thinking also appeared in a number of expert interviews, who emphasized that the production and organization was not optimal at these co-operatives or it became outdated by the late 1960s. In this sense local economic history and old routines blocked the transition towards a new organisational form, in spite of the clearly observable rural restructuring at the national scale.

\section{The 'Hungarian model' (1960-1989)}

Political and economic dependency on the Soviet Union started to loosen from the mid-1950s. Hungary was in short supply of western capital and up-to-date technology, hence the country started to look for the possibilities of Western partnerships and assistance. Besides the international trade on the capitalist world market, the acceptance of western loans started in this period (Böröcz 1992; Gerőcs \& Pinkasz 2017). The agricultural production became influenced by the global 'second food regime' (McMichael 2009), which meant the shift towards industrialised agriculture and changes in the goods produced. 
With the distancing from Stalinist planned economy, a gradually broadening economic liberalisation took place. In agriculture, these reforms were set in the first half of the 1960s. On the one hand, the former strict central control of state farms was replaced by freedom in terms of strategic decisions, while on the other hand, agricultural expertise became more important than political trustworthiness when it came to the nomination of farm leaders (Izinger 1983; Varga 2010). As a result, state farms initiated experiments on making the production more oriented towards the global markets (Varga 2014). The state farm, which held manor no. I. was prominent in these reforms: by the end of the 1970s it became nationally and internationally renowned, and built several international connections, also with western firms and adopted western-type industrialised agriculture (Schlett 2015; Varga 2010).

By the beginning of the 1970s a large landconcentration took place; the number of agricultural companies fell, while the size of the land held by them grew. Another important feature of this era was the evolution of small-scale farming (háztáji) due to the legalisation of private production. The original idea behind this reform step was that families would produce vegetables and pork or other kind of meat for their own consumption (as it occurred at pre-World War II large estates), but in practice, most of the rural population started to act like agricultural entrepreneurs, and sold most of the goods they produced. In many cases the co-operatives had key roles in helping the production and selling products (see e. g. Gyáni et al. 2004; Hann 2003; Juhász 1999; Swain 1985; Vigvári \& Gerőcs 2017).

On the local scale the role of farm leadership grew, while the local state still had a weak impact on manorial settlements' development paths. The 'window of opportunity' opened by economic liberalisation led to innovative steps started by the agricultural intelligentsia of the state farms; these attempts were reinforced by positive feedback as they became successful on international markets. At manor no. I, the former technology, production profile and land use changed remarkably. Crop, corn, poultry and egg became the main products (Schlett 2015; Varga 2010). As two of the former inhabitants reported, changing production technologies and raising mechanisation levels, accompanied by the state farm's policy which encouraged moving from the manors to the nearby villages led to a significant wave of migration at manor no I. In the state farm which held manor no. II., this model of industrial agriculture was also adopted: the state farm developed several branches, including a couple of side-line industrial activities.

The co-operatives established at manors no. III. and IV. were annexed to neighbouring co-operatives at the beginning of the 1970s. This step meant that the most important means to influence local processes were taken from the local society. Interviews have shown that local inhabitants reacted to this 'external shock' by encouraging the younger generations to find a job outside the locality, or to leave the locality. Inhabitants' argument about the annexation was very similar in both manors, as most of them think it was unjust and not necessary. However, they think it was impossible to do anything against it, and pointless to get organised.

At the same time, the legalisation of farming at private plots turned out to be an important catalyst of path creation. This enabled a strategy of capital accumulation that was present in all the four localities analysed. Furthermore, a new rural configuration evolved through the co-operation between companies and individuals. Interviewees at manor no. III. reported that almost every family stall-fed pigs in their private gardens, which were given by the neighbouring state farm (which held manor no. II.). The co-operative members were responsible for taking care of them, and once the pigs were grown-up enough, the state farm also bought them. This strategy was not only a secure way of accumulating capital, but also was efficient, since the members received a certain amount of fodder, or had the possibility to grow it, which they could use to feed livestock. ${ }^{2}$

Privatisation and land (re)concentration (after 1989)

At the end of the 1980s the former state socialist countries undergone political and economic transition. Hungary's dependency on Western core states grew, as the country opened its economy to Western investors, and initiated intensifying global

\footnotetext{
$\overline{2}$ This developmental path of the localities analysed in our case studies was a general phenomenon throughout rural Hungary as it has already been revealed by several scholars (e. g. Gyáni et al. 2004; Hann 2003; Juhász 1999; Swain 1985; Varga 2014).
} 
relationships. The integration into the world economy is primarily happening through the European Union, which Hungary is a part of since 2004. In agriculture and first of all in food industry international investors appeared, and the presence of the 'corporate food regime' (McMichael 2009; Woods 2007) can also be observed.

The former central control of economic production was replaced by neoliberal policies and the restitution of market relations. In agriculture, the consequence of the transition was the privatisation of co-operatives and state farms. Co-operatives were sold or transformed by the mid-1990s, the privatisation of state farms demanded more time, and some of them remained nationalised until the 2000s (Klenczner 1996; Kovách 2016; Varga 2010). The large majority of co-operatives disbanded, which meant that the significance of large-scale farming diminished. As the former eastern markets were not reachable anymore, many agricultural branches and food industries downgraded. Not only large-scale livestock breeding diminished, but also market-oriented private breeding went through a remarkable fall, as this sub-system was only attractive until the socialist agricultural companies organised it (Agócs \& Agócs 1994; Kovács 2005). From the late 1990s a growing land concentration can be observed, and with the introduction of EU subsidies, landowners became even more interested in gaining land, which led to a revival of large-scale farms. In this process the former leaders of socialist agricultural companies have an important role, and a rising group of investors with good political connections can also be observed, while masses of rural population were excluded from agricultural production as business opportunity (Kovách 2016; Maurel 2012; Swain 2000).

On the scale of manorial settlements, case studies show that former farm leaders and new investors are the key actors of local path creation. It can be seen that the former subordination of these localities is renewing, as economic evolution is mainly formed by absentee owners and the role of land property relations is usually very strong. Local residents were usually not able to influence processes of privatisation and the evolutionary path of localities. In this sense, path dependency is an important feature, which emerges from local economic history. In the case of manor no. I., the state farm was sold to private investors, who are still using the majority of the old buildings for poultry and egg production. Due to the upgraded production technology, the workforce demand has diminished, but some of the locals still work there. Inhabitants' experience is that since the privatization of the state farm, working conditions and production quality worsened remarkably. In manor no. II. the production transformed more significantly as a foreign investor decided to finish beef and milk production and started to produce pork with a highly mechanised production method; the connection between the local population and the farm is observable no more. Due to the exclusion of local inhabitants from path creation mechanisms a wave of selective migration and growing unemployment can be observed and both manor no I. and manor no. II. are on the way of becoming 'slums' according to some of the inhabitants and experts.

At manor no. III. the co-operative was privatised mainly by the former farm leadership, which resulted in the closure of local employment possibilities. As this case study revealed, local governments also has a role in forming the rural configuration through regulating the land use possibilities around the manors: the local government responsible for manor no III. changed the land use regulation for a large part of the neighbouring lands, which now gives place to the largest industrial park in the county. In manor no. IV, the former co-operative transformed into a holding company. The company created new economic path by carrying out significant technological reforms and introducing new specialisations. The reforms made the company competitive, the main products are currently milk and potato. Certain elements of the rural configuration changed (such as the land use and production technologies), but continuity is also observable, as local inhabitants are still employed by the Ltd., and the company managed to carry on intensive large-scale farming.

\section{Conclusion}

We aimed to show how the integration of the rural restructuring approach and EEG can foster the comprehension of rural economic transformation in a postsocialist context. By framing the analysis on three different geographical scales, we attempted to point to the changing interrelatedness of the processes observable at these scales on the long-term. As emphasized 
above, the empirical scope of our analysis is specific, but some general conceptual statements can be done regarding the mechanisms shaping the rural configuration.

Looking at the global scale, the most important feature of the system we analysed is dependency, which means the national scale restructuring and local scale evolution are strongly influenced by international political and economic effects. Large-scale farms show a clear orientation towards international markets, which is observable during all the periods analysed, although under the Stalinist period the possibilities of western exchange were cut back. The role of global agri-food regimes (McMichael 2009) seems to be strong and this system of dependency has important consequences on the changing rural configuration by influencing the evolution of agri-food branches.

In terms of national scale processes, the changing political power relations had paramount impact on the local evolutionary paths of manorial settlements. Broadly speaking, as a result of the political transitions, the possibilities of individuals and firms were remarkably different during the different eras; the transitions can be seen as fundamental 'external shocks' (Martin \& Sunley 2006) to certain economic sectors. Furthermore, during state socialism, the state was the primary driver of economic transformations. Especially during the era of Stalinist planned economy the ways of path creation were constrained both through the strict central control of economic activities and due to the nationalisation of land, farms, and foundation of state-owned companies.

We were able to analyse the changing rural configuration through case studies. Documents on local history and agricultural census data was useful regarding the first two eras presented, while from the 1960s onwards we could gain insight into local evolutionary processes via interviews with different groups of local actors. On the local scale, the duality of path dependency and path creation characterizes the settlements analysed. The historically continuous subordination and passivity of the local society is present during all the four periods, and constitute an important feature of rural configuration. Path creation is usually initiated by farm leadership, or the agricultural intelligentsia during times when economic liberalisation opened up 'windows of opportunity'. The case studies presented show that during the last century, manorial settlements have been considered by local actors as places of economic production first of all, and not places of residence, which is apparent if we look at the moderate role of the local state in shaping the rural configuration.

With the revival of large-scale farming during the 2010s, and the growing role of property relations, it is expected that the localities analysed will move towards further exclusion of local population from path creation processes. The impact of foreign capital and national absentee owners seem to strengthen as the neoliberal turn of state policies becomes dominant and the land concentration grows.

Acknowledgement Open access funding provided by Eötvös Loránd University. The article is an outcome of Campus Mundi mobility programme, funded by the Tempus Public Foundation.

\section{Compliance with ethical standards}

Conflict of interest György Mikle took part in the following: Campus Mundi international mobility programme, funded by the Tempus Public Foundation.

Open Access This article is licensed under a Creative Commons Attribution 4.0 International License, which permits use, sharing, adaptation, distribution and reproduction in any medium or format, as long as you give appropriate credit to the original author(s) and the source, provide a link to the Creative Commons licence, and indicate if changes were made. The images or other third party material in this article are included in the article's Creative Commons licence, unless indicated otherwise in a credit line to the material. If material is not included in the article's Creative Commons licence and your intended use is not permitted by statutory regulation or exceeds the permitted use, you will need to obtain permission directly from the copyright holder. To view a copy of this licence, visit http://creativecommons.org/licenses/by/4.0/.

\section{References}

Agócs, P., \& Agócs, S. (1994). Too little, too late: the agricultural policy of Hungary's post-communist government. Journal of Rural Studies, 10(2), 117-130. https://doi.org/ 10.1016/0743-0167(94)90024-8.

Balogh, A., \& Bajmócy, P. (2011). Majorok a Nyugat-Dunántúlon. Szombathely: Savaria University Press.

Beluszky, P. (1999). Magyarország településföldrajza: Általános rész. Budapest: Dialóg Campus Kiadó.

Berend, T. I., \& Ránki, Gy. (1976). Közép-Kelet Európa gazdasági fejlödése a 19-20 században. Budapest: Közgazdasági és Jogi Kvk.

Boschma, R., \& Frenken, K. (2006). Why is economic geography not an evolutionary science?: Towards an evolutionary economic geography. Journal of Economic 
Geography, 6(3), 273-302. https://doi.org/10.1016/S07430167(97)00053-3.

Boschma, R., \& Martin, R. (2007). Constructing an evolutionary economic geography. Journal of Economic Geography, 7(5), 537-548. https://doi.org/10.1093/jeg/lbm021

Boschma, R., \& Martin, R. (2010). The handbook on evolutionary economic geography. Cheltenham: Edward Elgar.

Böröcz, J. (1992). Dual dependency and property vacuum: social change on the state socialist semiperiphery. Theory and Society, 21(1), 77-104. https://doi.org/10.2478/eec2018-0005.

Brenner, R. (1976). Agrarian class structure and economic development in pre-industrial Europe. Past and Present., 70, 30-74.

Cloke, P. (1989). Rural geography and political economy. In R. Peet \& N. Thrift (Eds.), New models in geography: The political economy perspective (pp. 164-197). London: Unwin Hyman.

Cloke, P. (1997). Country backwater to virtual village? Rural studies and 'the cultural turn'. Journal of Rural Studies, 13, 367-375. https://doi.org/10.1093/jeg/lbm022.

Cloke, P., \& Thrift, N. (1987). Intra-class conflict in rural areas. Journal of Rural Studies, 3(1), 311-333. https://doi.org/10. 1016/0743-0167(87)90051-9.

Csoóri, S. (1963). Puszta az orgonásdomb alatt. In Tudósítás a toronyból (pp. 5-35). Budapest, Hungary: Magvető.

Csurgó, B., Kovách, I., \& Megyesi, B. (2018). After a long march: The results of two decades of rural restructuring in Hungary. Eastern European Countryside, 24(1), 81-109. https://doi.org/10.2478/eec-2018-0005.

Erdei, F. (1974). Magyar falu. Budapest: Akadémiai Kiadó.

Essletzbichler, J., \& Rigby, D. (2007). Exploring evolutionary economic geographies. Journal of Economic Geography, 7(5), 549-571. https://doi.org/10.1016/S0743-0167(00) 00037-1.

Féja, G. (1938). Viharsarok: az Alsó-Tiszavidék földje és népe. Budapest: Athenaeum Kiadó.

Friedmann, H., \& McMichael, P. (1989). Agriculture and the state system: The rise and decline of national agricultures, 1870 to the present. Sociologia Ruralis, 29(2), 93-117. https://doi.org/10.1111/j.1467-9523.1989.tb00360.x.

Geels, F. (2012). The multi-level perspective on sustainability transitions: responses to seven criticisms. Environmental Innovation and Societal Transitions, 1, 24-40. https://doi. org/10.1016/j.eist.2011.02.002.

Geröcs, T., \& Pinkasz, A. (2017). A KGST a világrendszerben: Egy félperifériás kísérlet gazdaságtörténeti elemzése. Eszmélet, 29(113), 15-36.

Giddens, A. (1984). The constitution of society: Outline of the theory of structuration. Berkeley, US: University of California Press.

Gunst, P. (1970). A mezőgazdasági termelés története Magyarországon (1920-1938). Budapest: Akadémiai Kiadó.

Gyáni, G., Kövér, Gy, \& Valuch, T. (2004). Social history of Hungary from the Reform Era to the end of the twentieth century. New York: Columbia University Press.

Győri, R., \& Mikle, Gy. (2017). A fejlettség területi különbségeinek változása Magyarországon, 1910-2011. Tér és Társadalom, 31(3), 143-165. https://doi.org/10.1080/ 00130095.2018.1498294.
Hann, C. M. (2003). The postsocialist agrarian question: Property relations and the rural condition. Münster: Lit.

Hoggart, K., \& Paniagua, A. (2001a). What rural restructuring? Journal of Rural Studies, 17(1), 41-62. https://doi.org/10. 1111/j.1468-2427.1986.tb00026.x.

Hoggart, K., \& Paniagua, A. (2001b). The restructuring of rural Spain? Journal of Rural Studies, 17(1), 63-80. https://doi. org/10.1093/jeg/lb1012.

Illyés, Gy. (1993). Puszták népe. Budapest: Századvég.

Izinger, P. (1981). Az első évtized: Az állami gazdaságok 1945-1956 között. Valóság, 6, 26-40. https://doi.org/10. 1080/03066150902820354.

Izinger, P. (1983). A harmadik évtized: Az állami gazdaságok 1968-1980 között. Valóság, 3, 38-45. https://doi.org/10. 1111/soru.12249.

Juhász, P. (1999). Mai képünk a parasztságról s a falusi társadalom néhány jellegzetességéről. In N. Fokasz \& A. Örkény (Eds.), Magyarország társadalomtörténete III/2.: 1945-1989: Válogatott tanulmányok (pp. 230-324). Budapest: Új Mandátum Könyvkiadó.

Juhász, P. (2006). Emberek és intézmények: Két zsákutca az agráriumban. Budapest: Új Mandátum Kiadó-Jelenkutató Alapítvány.

Klenczner, A. (1996). Az állami gazdaságokról. In I. Orosz, L. Für, \& P. Romány (Eds.), Magyarország agrártörténete: agrártörténeti tanulmányok (pp. 697-698). Budapest: Mezőgazda Kiadó.

Kovách, I. (2012). Vidék az ezredfordulón: A jelenkori magyar vidéki társadalom szervezeti és hatalmi változásai. Budapest: Argumentum.

Kovách, I. (2016). Földek és emberek: Földhasználók és földhasználati módok Magyarországon. Debrecen: MTA Társadalomtudományi Kutatóközpont, Debreceni Egyetemi Kiadó.

Kovács, T. (2005). Restructuring agriculture. In Gy Barta, É. G. Fekete, I. Szörényiné Kukorelli, \& J. Timár (Eds.), Hungarian spaces and places: patterns of transition (pp. 259-271). Pécs: Centre for Regional Studies of the Hungarian Academy of Sciences.

Kovács, K. (2016). Földböl élök: Polarizáció a magyar vidéken. Budapest: Argumentum.

Kovács, É., \& Vidra, Zs. (2012). Kényszer, vagy kivonulás: élet a peremeken. Tér és Társadalom, 26(4), 73-92. https://doi. org/10.1515/subbs-2017-0006.

Lampland, M. (2016). The Value of Labor: The Science of Commodification in Hungary, 1920-1956. Chicago: The University of Chicago Press.

MacKinnon, D., Dawley, S., Pike, A., \& Andrew, A. (2019). Rethinking path creation: A geographical political economy approach. Economic Geography, 95(2), 113-135. https://doi.org/10.1080/00130095.2018.1498294.

Maclaren, A. S. (2019). Rural geographies in the wake of nonrepresentational theories. Geography Compass, 3(8), 1-12. https://doi.org/10.1111/gec3.12446.

Martin, R., \& Sunley, P. (2006). Path dependence and regional economic evolution. Journal of Economic Geography, 6(4), 395-437. https://doi.org/10.1093/jeg/lb1012.

Maurel, M. (2012). Large farms in Central Europe: An unchanging spatio-temporal feature? Études rurales, 190(2), 25-47. 
McMichael, P. (2009). A food regime genealogy. The Journal of Peasant Studies, 36(1), 139-169. https://doi.org/10.1080/ 03066150902820354.

Mendöl, T. (1963). Általános településföldrajz. Budapest: Akadémiai Kiadó.

Mikle, Gy. (2018). Hungarian manors in changing historicalpolitical contexts: the role of the institutional environment. In F. Bódog, B. Csiszár, Z. S. Hayden, O. Kovács \& T. Rácz (Eds.), VII. Interdiszciplináris doktorandusz konferencia 2018. Tanulmánykötet, (pp. 220-232). Pécs, Hungary: Pécsi Tudományegyetem Doktorandusz Önkormányzat.

Molnár, I. \& Szabóné Medgyesi, É. (1987). Állami Gazdaságok Magyarországon. Budapest: Mezőgazdasági Kiadó.

Morris, C., \& Evans, N. (2004). Agricultural turns, geographical turns: retrospect and prospect. Journal of Rural Studies, 20, 95-111. https://doi.org/10.1016/S0743-0167(03)00041-X.

Németh, K. (2016). Mobilitási utak egy mezőgazdasági nagyüzem dicsfényében és árnyékában. In K. Kovács (Ed.), Földböl elök: Polarizáció a magyar videken (pp. 162-185). Budapest: Argumentum Kiadó.

Németh, K. (2019). Trapped in the past? The reproduction of poverty and marginality in a Hungarian manorial village. Sociologia Ruralis, 59(3), 419-446. https://doi.org/10. 1111/soru.12249

Pósfai, Zs. (2018). Reproducing uneven development on the Hungarian housing market. Szeged: Doktori értekezés, Szegedi Tudományegyetem, Földtudományok Doktori Iskola.

Randelli, F., \& Martellozzo, F. (2019). Is rural tourism-induced built-up growth a threat for the sustainability of rural areas? The case study of Tuscany. Land Use Policy, 86, 387-398. https://doi.org/10.1016/j.landusepol.2019.05.018.

Randelli, F., Romei, P., \& Tortora, M. (2014). An evolutionary approach to the study of rural tourism: The case of Tuscany. Land Use Policy, 38, 276-281. https://doi.org/10. 1016/j.landusepol.2013.11.009.

Schlett, A. (2015). The Socialist-type process of innovation: lessons of Hungarian Agrarian modernization between 1960 and 1990. Hungarian Historical Review: New Series of Acta Historica Academiae Scientiarium Hungaricae, 4(4), 900-927.

Sik, E., \& Tausz, K. (1978). Az uradalmi cselédség és a földosztás. In P. Léderer (Ed.), Egy szociológiai diákkör munkáiból, OM Marxizmus-Leninizmus Okt (pp. 15-43). Budapest, Hungary: Főoszt.

Swain, N. (1985). Collective Farms which Work?. Cambridge: Cambridge University Press.

Swain, N. (2000). From Kolkhoz to Holding company: A Hungarian agricultural producer co-operative in transition. Journal of Historical Sociology, 13(2), 142-171. https:// doi.org/10.1111/1467-6443.00111.

Tamáska, M. (2013). Falvak az uradalmak helyén: a megszünt nagybirtok telepes községeinek épitészete 1945 után. Budapest: Martin Opitz Kiadó.

Thrift, N. (1987). Manufacturing rural geography? Journal of Rural Studies, 3, 77-81. https://doi.org/10.1016/07430167(87)90011-8.

Varga, Zs. (2010). Between East and West: a cultic place of the Hungarian agriculture-Bábolna Farm. In A. Halmesvirta (Ed.), Cultic revelations: Cult personalities and phenomena (pp. 161-180). Jyväskylä: University of Jyväskylä, Faculty Of Humanities, Department of Art and Culture Studies, Hungarian Studies.

Varga, Zs. (2014). Modelltranszferek Keletröl és Nyugatról: mezögazdasági termelöszövetkezetek Magyarországon (1949-1989). Budapest: ELTE.

Vigvári, A., \& Gerőcs, T. (2017). The concept of "peasant embourgeoisement' in the perspective of different historical conjunctures. Studia UBB Sociologia, 62(1), 85-104. https://doi.org/10.1515/subbs-2017-0006.

Wallerstein, I. (1974). The modern world system: Capitalist agriculture and the European world economy in the sixteenth century. New York: Academic Press.

Woods, M. (2005). Rural geography: Processes, responses and experiences in rural restructuring. London: SAGE.

Woods, M. (2007). Engaging the global countryside: globalization, hybridity and the reconstitution of rural place. Progress in Human Geography, 31(4), 485-507.

Woods, M. (2009). Rural geography: Blurring boundaries and making connections. Progress in Human Geography, 33(6), 849-858. https://doi.org/10.1177/030913250810 5001.

Publisher's Note Springer Nature remains neutral with regard to jurisdictional claims in published maps and institutional affiliations. 